4th National Seminar on Guidance and Counseling (SNBK 2019) and Workshop on

Pedagogical Theory and Practice (WTPP 2019)

SHEs: Conference Series 2 (2) (2019) $80-87$

\title{
Penerapan Model Pembelajaran Think, Pair, and Share Terhadap Peningkatan Hasil Belajar Siswa Pada Pembelajaran IPS di Kelas V SD Negeri I Bojonggambir
}

\author{
Arini Ainaki Nur Dinaqi ${ }^{1}$, Cece Rakhmat ${ }^{2}$, Fajar Nugraha ${ }^{3}$ \\ ${ }^{1,3}$ Universitas Perjuangan Tasikmalaya, ${ }^{2}$ Universitas Pendidikan Indonesia \\ ariniainakinurdinaqi@gmail.com
}

\section{Article History}

accepted 2/11/2019

approved 23/11/2019

published 31/12/2019

\begin{abstract}
The problem in this study is the low student learning outcomes in social studies learning in Class V SD Negeri I Bojonggambir, Bojonggambir sub-district, Tasikmalaya Regency. The purpose of this study is to improve student learning outcomes in social studies learning material for the proclamation of Indonesian independence by using the Think, Pair, and Share (TPS) learning model in fifth grade students of SD Negeri 1 Bojonggambir, Kab. Tasikmalaya, 2018/2019 school year. The method used in this research is classroom action research (CAR). The results showed that there was an increase in social studies learning outcomes using Think, Pair, and Share learning models, the average student pre-action scores were 53.21, which reached 8 students (28.5\%) and had not yet reached 20 students $(71.4 \%)$. Cycle I increased by 8.21 with an average score of 60.71 , which reached 15 students (53.6\%) and 13 students (46.4\%) incomplete. Cycle II increased by 18.93 from cycle I, whereas when compared with pre-action it increased by 27.14 with an average score of 80.35 , completing 25 students (89.2\%) and 3 students (10.8\%) incomplete. The implication of this research is the use of Think, Pair, and Share (TPS) learning models on social studies learning for Indonesian independence proclamation material can improve student learning outcomes.
\end{abstract}

\section{Keywords: TPS, learning outcomes, social studies}

\begin{abstract}
Abstrak
Masalah dalam penelitian ini adalah rendahnya hasil belajar siswa pada pembelajaran IPS di Kelas V SD Negeri I Bojonggambir, kecamatan Bojonggambir, Kabupaten Tasikmalaya. Tujuan penelitian ini adalah meningkatkan hasil belajar siswa pada pembelajaran IPS materi proklamasi kemerdekaan Indonesia dengan menggunakan model pembelajaran Think, Pair, and Share (TPS) pada siswa kelas V SD Negeri 1 Bojonggambir, kab. Tasikmalaya, tahun ajaran 2018/2019. Metode yang digunakan dalam penelitian ini adalah penelitian tindakan kelas (PTK). Hasil penelitian menunjukkan bahwa adanya peningkatan hasil belajar IPS dengan menggunakan model pembelajaran Think, Pair, and Share, pratindakan nilai rata-rata siswa adalah 53.21, yang mencapai ketuntasan sebanyak 8 siswa $(28.5 \%)$ dan belum mencapai ketuntasan 20 siswa (71.4\%). Siklus I meningkat sebanyak 8.21 dengan nilai rata-rata adalah 60.71 , yang mencapai ketuntasan 15 siswa (53.6\%) dan belum tuntas 13 siswa (46.4\%). Siklus II meningkat sebanyak 18.93 dari siklus I, sedangkan jika dibandingkan dengan pratindakan meningkat sebanyak 27.14 dengan nilai rata-rata menjadi 80.35 , yang mencapai ketuntasan 25 siswa $(89.2 \%)$ dan belum tuntas 3 siswa (10.8\%). Implikasi penelitian ini adalah penggunaan model model pembelajaran Think, Pair, and Share (TPS) pada pembelajaran IPS materi proklamasi kemerdekaan Indonesia dapat meningkatkan hasil belajar siswa.
\end{abstract}

Kata Kunci: TPS, Hasil belajar, IPS

Social, Humanities, and Education Studies (SHEs): Conference Series https://jurnal.uns.ac.id/shes

p-ISSN 2620-9284

e-ISSN 2620-9292 


\section{PENDAHULUAN}

IImu Pengetahuan Sosial (IPS) merupakan mata pelajaran yang berada di setiap jenjang pendidikan, diantaranya yaitu SD, SMP, SMA, dan Perguruan Tinggi. IPS di jenjang pendidikan tersebut mempunyai arti yang berbeda-beda yang disesuaikan dengan karakteristik siswa-siswanya di tingkat persekolahan. Sapriya (2014) menyatakan bahwa

"IImu pengetahuan sosial atau yang sering disebut IPS merupakan nama mata pelajaran di tingkat sekolah dasar, menengah, dan perguruan tinggi. Namun pengertian IPS di tingkat persekolah itu mempunyai perbedaan makna yang disesuaikan dengan karakterisktik dan kebutuhan peserta didik, khususnya IPS untuk Sekolah Dasar (SD)".

IImu pengetahuan sosial pada jenjang sekolah dasar (SD) merupakan mata pelajaran terpadu yang menggabungkan beberapa mata pelajaran seperti sejarah, ekonomi, dan geografi, yang mempunyai fungsi untuk mengembangkan pengetahuan dan keterampilan yang berguna bagi dirinya dalam kehidupan sehari-hari. Kurikulum 2004 (Nurdin, 2018) menyatakan bahwa "IPS di SD berfungsi untuk mengembangkan pengetahuan nilai, sikap, dan keterampilan siswa tentang masyarakat, bangsa dan Negara Indonesia". Keterampilan sosial tersebut memberi bekal siswa untuk menyelesaikan perselisihan dalam interaksi dengan teman nya (Nugraha dan Zahrah, 2019). Oleh karena itu, mata pelajaran IPS merupakan mata pelajaran yang sangat penting, karena pada hakikatnya IPS merupakan gabungan dari beberapa ilmu yang dapat membantu manusia untuk mengembangkan kemampuan yang dimilikinya.

Berdasarkan hasil observasi di SD Negeri 1 Bojonggambir, permasalahan yang terjadi pada pembelajaran IPS diantaranya rendahnya daya serap siswa dalam memahami pelajaran IPS, proses pembelajaran masih bersifat individu dan kurang bekerjasama antara siswa dan siswa lainnya, penyampaian materi pembelajaran masih terpaku pada buku paket saja belum ada variasi yang lain sehingga timbul kebosanan dan kejenuhan pada siswa. 65\% siswa menganggap bahwa mata pelajaran IPS merupakan mata pelajaran yang harus banyak membaca dan mencatat. Hal tersebut mengakibatkan hasil belajar siswa pada mata pelajaran IPS rendah, karena banyak siswa yang mendapatkan nilai di bawah KKM dan hanya sedikit siswa yang mendapatkan nilai di atas KKM. Nilai KKM yang sudah ditentukan oleh sekolah pada mata pelajaran IPS di kelas $\mathrm{V}$ adalah 67 . Berdasarkan data yang di peroleh dari guru kelas $\mathrm{V}$ bahwa pada mata pelajaran IPS 20 siswa atau $71 \%$ siswa masih di bawah nilai KKM, sedangkan 8 siswa atau 29\% siswa sudah mencapai KKM. Oleh karena itu dapat terlihat bahwa hasil belajar siswa pada mata pelajaran IPS di kelas $\mathrm{V}$ masih rendah.

Hasil belajar merupakan suatu yang penting dalam pembelajaran, karena hasil belajar menjadi ukuran keberhasilan proses pembelajaran. Kurniawan, dkk (2017) menyatakan bahwa "Hasil belajar merupakan salah satu komponen yang penting dalam proses pembelajaran, karena hasil belajar merupakan tolak ukur keberhasilan suatu proses pembelajaran". Keberhasilan suatu proses pembelajaran dipengaruhi oleh keterampilan guru dalam menggunakan suatu metode dan model pembelajaran yang lebih efektif dan efisien, termasuk di dalamnya sarana, prasarana belajar guna menunjang proses yang positif terhadap hasil belajar siswa. Model pembelajaran merupakan salah satu cara atau rencana dalam menjelaskan materi agar siswa mudah dan lebih cepat memahami. Trianto dalam Afandi, dkk (2013) menyatakan bahwa "model pembelajaran adalah suatu perencanaan atau pola yang digunakan sebagai pedoman dalam merencanakan pembelajaran di kelas atau pembelajaran tutorial". Oleh karena itu, model pembelajaran adalah cara atau teknik penyajian sistematis yang digunakan oleh guru dalam mengorganisasikan pengalaman proses pembelajaran agar tercapai tujuan dari suatu pembelajaran. Upaya menciptakan 
pembelajaran yang sesuai dengan tujuan tersebut guru sebaiknya menerapkan metode diskusi dengan menggunakan model pembelajaran Think, Pair, and Share (TPS). Model pembelajaran Think, Pair, and Share (TPS) merupakan jenis pembelajaran kooperatif yang dirancang untuk mempengaruhi pola interaksi siswa, (Hamdayana: 2017). Model ini dapat mengembangkan pengetahuan siswa melalui diskusi bersama temannya, berbagi pendapat, dan meningkatkan hasil belajar siswa di kelas. Berdasarkan latar belakang masalah di atas, maka peneliti sudah melaksanakan penelitian dengan judul "Penerapan Model Pembelajaran Think, Pair, and Share Terhadap Peningkatan Hasil Belajar Siswa Pada Pembelajaran IPS Di Kelas V SD Negeri 1 Bojonggambir".

\section{METODE}

Metode yang digunakan dalam penelitian ini adalah metode penelitian tindakan kelas (PTK). Penelitian tindakan kelas adalah penelitian yang mengkombinasikan prosedur penelitian dengan tindakan substansif, suatu tindakan yang dilakukan dalam disiplin inkuiri, atau suatu usaha seseorang untuk memahami apa yang sedang terjadi, sambil terlibat dalam sebuah proses perbaikan dalam perubahan (Hopkins dalam Wiriaatmadja, 2014:11). Alasan peneliti mengambil penelitian tindakan kelas (PTK), karena penelitian ini merupakan salah satu upaya khususnya calon guru untuk meningkatkan dan memperbaiki mutu pembelajaran di kelas.

Desain penelitian yang digunakan dalam penelitian ini adalah desain penelitian yang mengacu pada model Kemmis dan McTaggart. Menurut Kesuma, (2013:33) tahapan penelitian tindakan kelas yang banyak digunakan adalah model Kemmis dan McTaggart yaitu berupa 1) perencanaan, 2) pelaksanaan tindakan, 3) pengamatan, dan 4)refleksi. Tahapan ini dilakukan dalam satu siklus, kemudian dilanjutkan di siklus berikutnya dengan tahapan yang sama setelah dilakukan refleksi di siklus pertama.

Penelitian ini dilaksanakan di SD Negeri 1 Bojonggambir, Desa Bojonggambir, kecamatan Bojonggambir, Kab. Tasikmalaya. Objek penelitiannyaa seluruh siswa kelas $\mathrm{V}$ yang berjumlah 28 orang siswa. Laki-laki terdiri dari 15 orang siswa dan perempuan terdiri dari 13 orang siswa. Dilaksanakan pada tanggal 03 Mei 2019 dan 14 Juni 2019 .

Teknik pengumpulan data dalam penelitian ini digunakan beberapa metode pengumpulan data yaitu:

1. Tes

Tes merupakan rangkaian pertanyaan yang memerlukan jawaban testi sebagai alat ukur dalam proses asesmen maupun evaluasi (Kasmadi dan Sunariah, 2014:69). Tes dalam penelitian ini digunakan untuk mengetahui perkembangan hasil belajar siswa pada pelajaran IPS di kelas V.

\section{Observasi}

Observasi adalah pengamatan dan pencatatan secara sistematik terhadap gejala yang tampak pada objek penelitian. (Sujarweni, 2014:75). Observasi dalam penelitian ini dilakukan dengan cara menggunakan instrumen yang sudah dirancang sebelumnya, misalnya instumen pada penilaian mengajar guru.

3. Dokumentasi

Dokumentasi yaitu hasil dari penelitian untuk memperoleh atau mengetahui sesuatu yang berhubungan dengan yang diteliti. Dokumentasi digunakan untuk memperoleh data sekolah, seperti daftar nama siswa, profil sekolah, keadaan siswa, keadaan guru dan karyawan, keadaan sarana dan prasarana serta foto tindakan kelas pada saat penelitian. 
4th National Seminar on Guidance and Counseling (SNBK 2019) and Workshop on

Pedagogical Theory and Practice (WTPP 2019)

SHEs: Conference Series 2 (2) (2019) $80-87$

HASIL DAN PEMBAHASAN

Tabel 1. Hasil belajar siswa pratindakan

\begin{tabular}{|c|c|c|c|c|c|}
\hline Tindakan & \multicolumn{2}{|c|}{ Kriteria Ketuntasan } & \multicolumn{2}{|c|}{$\begin{array}{c}\text { Presentasi } \\
\text { Ketuntasan }\end{array}$} & $\begin{array}{c}\text { Nilai } \\
\text { Rata- } \\
\text { rata }\end{array}$ \\
\cline { 2 - 5 } & Tuntas & $\begin{array}{c}\text { Belum } \\
\text { Tuntas }\end{array}$ & Tuntas & $\begin{array}{c}\text { Belum } \\
\text { Tuntas }\end{array}$ & \\
\hline Pratindakan & 8 & 20 & $28.5 \%$ & $71.4 \%$ & 53.21 \\
\hline
\end{tabular}

Berdasarkan tabel 1 maka dapat dijelaskan bahwa kondisi awal hasil belajar siswa pada mata pelajaran IPS di kelas V SD Negeri 1 Bojonggambir masih di bawah nilai KKM yaitu 67. Jumlah seluruh siswa yang banyaknya 28 orang, hanya 8 siswa atau $28.5 \%$ sudah tuntas atau mencapai KKM, sedangkan 20 orang siswa atau $71.4 \%$ belum tuntas atau belum mencapai KKM. Nilai rata-rata kelas yang diperoleh sebesar 53.21. Proses pembelajaran juga siswa masih kurang aktif, bahkan sering bicara sendiri dengan teman sebangkunya. Apabila guru memberikan pertanyaan, siswa cenderung menjawab secara bersama-sama, belum mempunyai keberanian menjawab pertanyaan secara individu, dalam proses pembelajaran siswa yang pandai akan semakin pandai, tetapi siswa yang kurang pandai semakin tidak termotivasi mengikuti pembelajaran.

Tabel 2. Hasil belajar siswa siklus I

\begin{tabular}{|c|c|c|c|c|c|}
\hline \multirow{2}{*}{$\begin{array}{c}\text { Jumlah } \\
\text { Siswa }\end{array}$} & \multicolumn{2}{|c|}{ Kriteria Ketuntasan } & \multicolumn{2}{|c|}{$\begin{array}{c}\text { Presentasi } \\
\text { Ketuntasan }\end{array}$} & $\begin{array}{c}\text { Nilai } \\
\text { Rata- } \\
\text { rata }\end{array}$ \\
\cline { 2 - 5 } & Tuntas & $\begin{array}{c}\text { Belum } \\
\text { Tuntas }\end{array}$ & Tuntas & $\begin{array}{c}\text { Belum } \\
\text { Tuntas }\end{array}$ & \\
\hline 28 & 15 & 13 & $53.6 \%$ & $46.4 \%$ & 61.42 \\
\hline
\end{tabular}

Tabel 2 menunjukkan bahwa hasil belajar siswa dengan menggunakan model pembelajaran Think, Pair, and Share pada siklus I diperoleh 13 orang siswa atau 46.4\% siswa belum tuntas, dan 15 orang siswa atau 53.6\% siswa telah tuntas dalam pembelajaran IPS menggunakan model pembelajaran Think, Pair, and Share (TPS), sehingga hasil belajar siswa pada siklus I telah meningkat, tetapi walaupun sudah meningkat hasil belajar siswa belum mencapai nilai KKM, sehingga perlu perbaikan atau dilanjutkan ke siklus II.

Tabel 3. hasil belajar siswa siklus II

\begin{tabular}{|c|c|c|c|c|c|}
\hline \multirow{2}{*}{$\begin{array}{c}\text { Jumlah } \\
\text { Siswa }\end{array}$} & \multicolumn{2}{|c|}{ Kriteria Ketuntasan } & \multicolumn{2}{|c|}{$\begin{array}{c}\text { Presentasi } \\
\text { Ketuntasan }\end{array}$} & $\begin{array}{c}\text { Nilai } \\
\text { Rata- } \\
\text { rata }\end{array}$ \\
\cline { 2 - 5 } & Tuntas & $\begin{array}{c}\text { Belum } \\
\text { Tuntas }\end{array}$ & Tuntas & $\begin{array}{c}\text { Belum } \\
\text { Tuntas }\end{array}$ & \\
\hline 28 & 25 & 3 & $89.2 \%$ & $10.8 \%$ & 80.35 \\
\hline
\end{tabular}

Tabel 3 menunjukkan bahwa hasil belajar siswa dengan menggunakan model pembelajaran Think, Pair, and Share pada siklus II diperoleh 3 orang siswa atau $10.8 \%$ siswa belum tuntas, dan 25 orang siswa atau 89.2\% siswa telah tuntas dalam pembelajaran IPS menggunakan model pembelajaran Think, Pair, and Share (TPS), sehingga hasil belajar siswa pada siklus II telah meningkat dari hasil belajar siswa setelah siklus I, dan telah mencapai nilai KKM.

Pembahasan ini diuraikan mengenai perencanan pembelajaran, pelaksaanaan pembelajaran, dan peningkatan hasil belajar IPS dengan menggunakan model pembelajaran Think, Pair, and Share (TPS) materi proklamasi kemerdekaan Indonesia di kelas V SD Negeri I Bojonggambir. Perencanaan pembelajaran yang telah dilakukan 
diantaranya yaitu peneliti dan guru merencanakan waktu penelitian, peneliti dan guru sebagai kolaborator menyiapkan materi yang akan disampaikan kepada siswa, menyusun rencana pelaksanaan pembelajaran (RPP) IPS materi proklamasi Kemerdekaan Indonesia, menyusun lembar observasi, menyusun dan menyiapkan LKS dan soal evaluasi untuk siswa, peneliti mempersiapkan media gambar sesuai dengan materi yang diajarkan, dan mempersiapkan kamera yang akan digunakan untuk mendokumentasikan aktivitas siswa selama proses pembelajaran berlangsung. Pelaksanaan pembelajaran dilakukan selama 2 siklus dengan mengikuti langkahlangkah yang ada dalam RPP menggunakan model pembelajaran Think, Pair, and Share (TPS) pada materi proklamasi Kemerdekaan Indonesia. AITabany (2014:130) menyatakan bahwa "lagkah-langkah model pembelajaran Think, Pair, and Share adalah berpikir, berbagi, dan berpasangan".

Berdasarkan penelitian yang telah dilakukan penggunaan model pembelajaran Think, Pair, and Share (TPS) pada materi proklamasi kemerdekaan Indonesia ternyata dapat meningkatkan hasil belajar IPS siswa kelas V SD Negeri I Bojonggambir. Kasmadi dan Sunariah (2014:81) menyatakan bahwa "hasil belajar merupakan perubahan perilaku yang diperoleh siswa setelah melakukan kegiatan belajar". Hal ini dapat dilihat bahwa dengan menggunakan model pembelajaran Think, Pair, and Share (TPS) dalam proses pembelajaran dapat menarik perhatian siswa, model ini membantu siswa untuk berpikir dan bekerja sama dengan kelompok, sehingga dapat meningkatkan pemahaman siswa terhadap materi yang disampaikan oleh guru. Shoimin (2014:208) menyatakan bahwa "model pembelajaran Think, Pair and Share (TPS) adalah suatu model pembelajaran kooperatif yang memberi siswa waktu berpikir dan merespons serta saling bantu sama lain".

Penggunaan model pembelajaran Think, Pair and Share, guru dapat menerapkan berbagai media yang menarik dalam penyampaian materi sehingga siswa tidak merasa jenuh dan merasa diceramahi. Penggunaan model pembelajaran Think, Pair, and Share (TPS) selama 2 siklus telah menunjukkan bahwa peningkatan hasil belajar siswa pada pembelajaran IPS di kelas V SD Negeri I Bojonggambir dibuktikan dengan adanya peningkatan hasil belajar pada pratindakan ke siklus I dan siklus II. Kondisi awal menunjukkan hasil belajar siswa dari rata-rata pratindakan sebesar 53.21. Siswa yang belum tuntas sebanyak 20 siswa atau $71.2 \%$ dan siswa yang sudah tuntas sebanyak 8 siswa atau $28.5 \%$. Nilai siswa tertinggi adalah 90 dan nilai siswa terendah adalah 20, untuk itu perlu adanya tindakan untuk mengoptimalkan hasil belajar IPS di SD Negeri I Bojonggambir.

Siklus I dilaksanakan dalam satu kali pertemuan. Hasil pelaksanaan siklus I menunjukkan adanya peningkatan hasil belajar siswa dibandingkan dengan pra tindakan, setelah siklus I rata-rata nilai meningkat menjadi 61.42 dari sebelum tindakan 53.21. Perolehan tersebut meningkat 8.21 dari rata-rata sebelum tindakan siklus I. Siswa yang belum tuntas atau mendapat nilai di bawah KKM sebanyak 13 siswa $(46.4 \%)$, dan siswa yang tuntas atau mendapat nilai di atas KKM sebanyak 15 siswa (53.6\%). Hasil belajar siklus I walaupun sudah meningkat tetapi belum mencapai nilai KKM, sehingga ada perbaikan/ dilanjutkan ke siklus II.

Siklus II dilakukan dalam satu kali pertemuan, sama halnya dengan siklus I. Pada siklus II perubahan data yang diperoleh menunjukkan rata-rata hasil belajar IPS meningkat menjadi 80.35 dengan nilai tertinggi 100 dan terendah 40 dibandingakn dengan pra tindakan dan siklus I. Dapat dilihat dalam tabel berikut ini: 
4th National Seminar on Guidance and Counseling (SNBK 2019) and Workshop on

Pedagogical Theory and Practice (WTPP 2019)

SHEs: Conference Series 2 (2) (2019) $80-87$

Tabel 4. Perbandingan hasil belajar siswa pratindakan, siklus I dan siklus II

\begin{tabular}{|c|c|c|c|c|c|}
\hline Tindakan & \multicolumn{2}{|c|}{ Kriteria Ketuntasan } & \multicolumn{2}{c|}{$\begin{array}{c}\text { Presentasi } \\
\text { Ketuntasan }\end{array}$} & $\begin{array}{c}\text { Nilai } \\
\text { Rata- } \\
\text { rata }\end{array}$ \\
\cline { 2 - 5 } & Tuntas & $\begin{array}{c}\text { Belum } \\
\text { Tuntas }\end{array}$ & Tuntas & $\begin{array}{c}\text { Belum } \\
\text { Tuntas }\end{array}$ & \\
\hline Pratindakan & 8 & 20 & $28.5 \%$ & $71.4 \%$ & 53.21 \\
\hline Siklus I & 15 & 13 & $53.6 \%$ & $46.4 \%$ & 61.42 \\
\hline Siklus II & 25 & 3 & $89.2 \%$ & $10.8 \%$ & 80.35 \\
\hline
\end{tabular}

Tabel 4 menjelaskan bahwa hasil belajar siswa pada pelajaran IPS materi proklamasi Kemerdekaan Indonesia di kelas V SD Negeri I Bojonggambir, setelah siklus II rata-rata nilai meningkat menjadi 80.35 dari siklus I 61.42. Perolehan tersebut meningkat sebanyak 18.93, sedangkan jika dibandingkan dengan pratindakan ke siklus II nilai rata-rata meningkat sebanyak 27.14. Berikut ini dapat dilihat pada diagram adanya peningkatan hasil belajar siswa dari pra tindakan ke siklus I, kemudian ke siklus II:

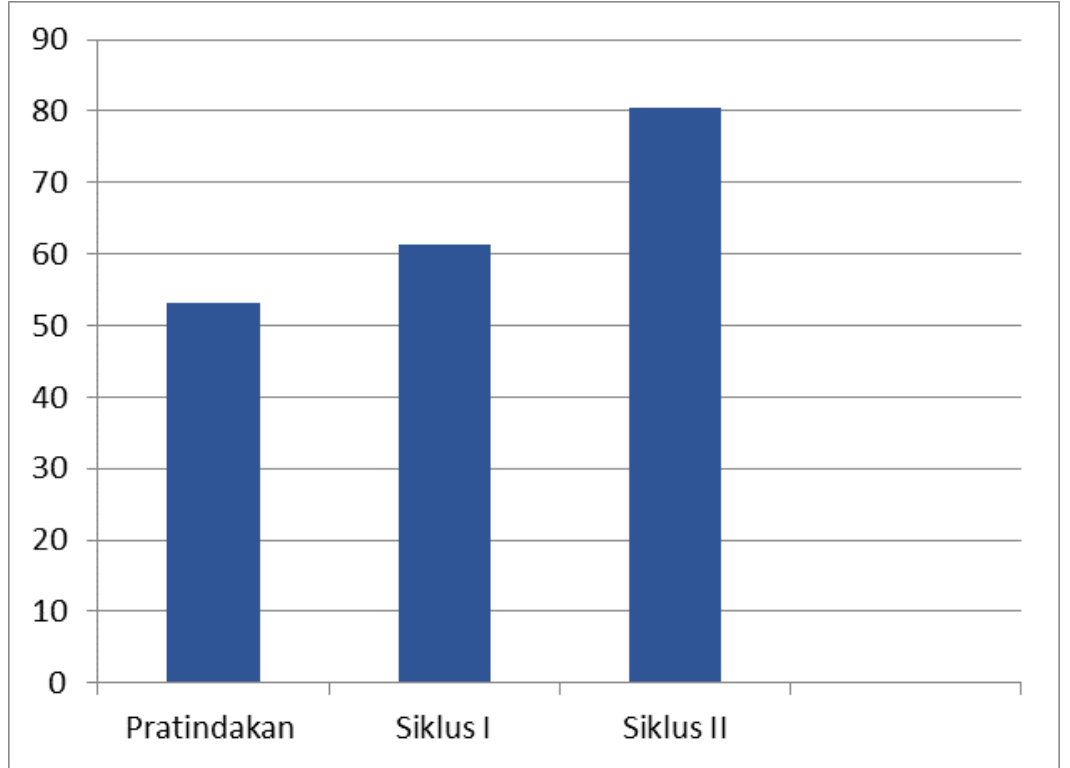

Diagram 1. Nilai rata-rata hasil belajar siswa pratindakan ke siklus I dan siklus II

Pelaksanaan penilaian kemampuan guru dalam proses mengajar pun mengalami peningkatan. Hal tersebut dapat dilihat pada tabel berikut ini:

Tabel 5. Hasil Perbandingansiklus I dan Siklus II Dalam APKG 1 dan APKG 2

\begin{tabular}{|l|c|c|c|c|c|c|}
\hline No & \multicolumn{2}{|c|}{ Penilaian } & $\begin{array}{c}\text { Jumlah } \\
\text { Indikator } \\
\text { yang dicapai }\end{array}$ & $\begin{array}{c}\text { Present } \\
\text { ase (\%) }\end{array}$ & $\begin{array}{c}\text { Rata- } \\
\text { rata }\end{array}$ & Kategori \\
\hline 1. & APKG & Siklus I & 29 & $90 \%$ & 3,62 & Baik \\
\cline { 2 - 7 } & 1 & Siklus II & 30 & $93 \%$ & 3,75 & $\begin{array}{c}\text { Sangat } \\
\text { Baik }\end{array}$ \\
\hline 2. & $\begin{array}{c}\text { APKG } \\
2\end{array}$ & Siklus I & 32.5 & $90 \%$ & 3,60 & Baik \\
\cline { 3 - 7 } & Siklus II & 35 & $97 \%$ & 3,80 & $\begin{array}{c}\text { Sangat } \\
\text { Baik }\end{array}$ \\
\hline
\end{tabular}


Berdasarkan tabel 4.8 dapat disimpulkan bahwa terdapat peningkatan kemampuan guru dari siklus I ke siklus II. APKG 1 pada siklus I jumlah indikator yang dicapai sebanyak 29 dengan presentase $90 \%$ dan memperoleh niai rata-rata 3.62, sedangkan pada siklus 2 jumlah indikator yang dicapai sebanyak 30 dengan presentase 93\% dan memperoleh nilai rata-rata 3.75. APKG 2 pada siklus I jumlah indikator yang dicapai sebanyak 32.5 dengan presentase $90 \%$ dan memperoleh niai rata-rata 3.60 , sedangkan pada siklus 2 jumlah indikator yang dicapai sebanyak 35 dengan presentase $97 \%$ dan memperoleh nilai rata-rata 3.75 .

\section{SIMPULAN}

1. Berdasarkan hasil pengolahan data dan analisis bahwa penerapan model pembelajaran Think, Pair, and Share dapat meningkatkan hasil belajar siswa pada pembelajaran IPS materi proklamasi kemerdekaan Indonesia di kelas V SD Negeri 1 Bojonggambir tahun ajaran 2018/2019. Hal tersebut dapat dilihat dari meningkatnya hasil belajar siswa pada setiap siklus, dari hasil penelitian dan pembahasan yang telah diuraikan, maka dapat diperoleh kesimpulannya sebagai berikut:

2. Perencanaan pembelajaran dengan menggunakan model pembelajaran Think, Pair, and Share dapat meningkatkan hasil belajar siswa sesuai analisis data pada siklus I dan siklus II.

3. Pelaksanaan pembelajaran dengan menggunakan model pembelajaran Think, Pair, and Share tidak hanya berpusat kepada guru (Teacher center), tetapi lebih melibatkan siswa (Student center), maka dengan penerapan model Think, Pair, and Share ini siswa akan lebih aktif dan dapat bekerja sama bersama teman kelompoknya, sehingga hal tersebut dapat meningkatkan hasil belajar siswa.

4. Hasil belajar pada pembelajaran IPS materi proklamasi Kemerdekan Indonesia dengan menggunakan model pembelajaran Think, Pair, and Share dapat meningkatkan hasil belajar siswa. Hal itu dapat dilihat dari hasil belajar siswa pada kondisi awal ke siklus I meningkat sebanyak 8.21 dengan nilai rata-rata pada kondisi awal adalah 53.21 dan meningkat pada siklus I menjadi 61.42, sedangkan dari siklus I ke siklus II hasil belajar siswa meningkat sebanyak 18.93, dengan ninlai rata-rata pada siklus II adalah 80.35,dan jika dilihat dari kondisi awal ke siklus II meningkat sebanyak 27.14.

\section{DAFTAR PUSTAKA}

Afandi, dkk. (2013). Model Dan Metode Pembelajaran. Semarang: Sultan Agung Press.

Al-Tabany, Trianto I. (2014). Mendaesain Model Pembelajaran Inovatif, Progresif, dan Kontekstual. Jakarta: Prenadamedia Group.

Hamdayana, Jumanta. (2017). Model dan Metode Pembelajaran Kreatif dan Berkarakter. Bogor : Ghalia Indonesia.

Huda, Miftahul. (2013). Model-model Pengajaran dan Pembelajaran. Yogyakarta: Pustaka Belajar.

Kasmadi., Sunariah, Nia S. (2014). Panduan Modern Penelitian Kuantitatif. Bandung: Alfabeta.

Kesuma, Ameliasari T. (2013). Menyusun PTK Itu Gampang. Jakarta: Erlangga.

Kurniawan, et al. (2017). Studi Analisis Faktor-faktor yang Mempengaruhi Hasil Belajar Pada Mata Pelajaran Teknik Listrik Dasar Otomotif. Jurnal Mechanical Engineering Education. Vol. 4. No. 2. 
Lestari., Yudhanegara, R. (2017). Penelitian Pendidikan Matematika. Bandung : Refika Aditama.

Muallimuna. (2016). Kedudukan IImu Pengetahuan Sosial di Sekolah Dasar. Jurnal Madrasah Ibtidaiyah. Vol. 2. No. 1.

Nugraha, F. Zahrah, R, F. (2018). Permainan Tradisonal "Kaulinan Barudak" Untuk Meningkatkan Kemampuan Bersikap Empati Siswa Kelas V Sekolah Dasar. Jurnal Visipena Vol. 9. No. 2

Nurdin, Sadjarudin., et al. (2018). Pengembangan dan Pendalaman Pendidikan IPS Sekolah Dasar. Tasikmalaya: UNPER.

Sapriya. (2014). Pendidikan IPS. Bandung : PT Remaja Rosdakarya.

Shoimin, Aris. (2014). 68 Model Pembelajaran Inovatif dalam Kurikulum. Yogyakarta: Ar-Ruzz Media.

Sudjana, N. (2014). Landasan Psikologi Pendidikan. Jakarta: Rineka Cipta.

Sujarweni,Wiratna. (2014). Metodologi Penelitian. Yogyakarta: Pustaka Baru Press.

Widodo. (2013). Peningkatan Aktivitas Belajar dan Hasil Belajar Siswa Dengan Metode Problem Based Learning. Jurnal Fisika Indonesia. Vol. 17. No. 49.

Windiyani, Tustiyana., et al. (2018). Penggunaan Media Pembelajaran Gambar Fotografi Pada Mata Pelajaran IPS SD. Jurnal Pendidikan Sekolah Dasar. Vol. 4. No. 1.

Wiriaatmadja, Rochiati. (2014). Metode Penelitian Tindakan Kelas. Bamdung: PT Remaja Rosdakarya. 